\title{
Involvement of NMDA receptor complex in the anxiolytic-like effects of chlordiazepoxide in mice
}

\author{
Ewa Poleszak $\cdot$ Katarzyna Socała $\cdot$ Aleksandra Szopa $\cdot$ \\ Andrzej Wróbel · Bernadeta Szewczyk · Regina Kasperek • \\ Eliza Blicharska $\cdot$ Gabriel Nowak $\cdot$ Piotr Wlaź
}

Received: 3 October 2010/ Accepted: 16 January 2011/Published online: 5 February 2011

(C) The Author(s) 2011. This article is published with open access at Springerlink.com

\begin{abstract}
In the present study, we demonstrated that low, ineffective doses of $N$-methyl-D-aspartic acid (NMDA) receptor antagonists [competitive NMDA antagonist, CGP 37849 , at $0.312 \mathrm{mg} / \mathrm{kg}$ intraperitoneally (i.p.), antagonist of the glycine $_{\mathrm{B}}$ sites, L-701,324, at $2 \mathrm{mg} / \mathrm{kg}$ i.p., partial agonist of glycine $_{B}$ sites, D-cycloserine, at $2.5 \mathrm{mg} / \mathrm{kg}$ i.p.] administered jointly with an ineffective dose of the benzodiazepine, chlordiazepoxide (CDP, $2.5 \mathrm{mg} / \mathrm{kg}$ i.p.), significantly increased the percentage of time spent in the open arms of the elevated plus-maze (index of anxiolytic effect). Furthermore, CDP-induced anxiolytic-like activity ( $5 \mathrm{mg} / \mathrm{kg}$ i.p.) was antagonized by NMDA ( $75 \mathrm{mg} / \mathrm{kg}$ i.p.)
\end{abstract}

E. Poleszak $(\varangle) \cdot$ A. Szopa $\cdot$ R. Kasperek

Department of Applied Pharmacy, Medical University of Lublin, Chodźki 1, 20-093 Lublin, Poland

e-mail: ewa.poleszak@umlub.pl

K. Socała · P. Wlaź $(\bowtie)$

Department of Animal Physiology, Institute of Biology,

Maria Curie-Skłodowska University,

Akademicka 19, 20-033 Lublin, Poland

e-mail: piotr.wlaz@umcs.lublin.pl

\section{A. Wróbel}

Second Department of Gynecology, Medical University of Lublin, Lublin, Poland

B. Szewczyk · G. Nowak

Department of Neurobiology, Institute of Pharmacology,

Polish Academy of Sciences, Kraków, Poland

E. Blicharska

Department of Analytical Chemistry, Medical University of Lublin, Lublin, Poland

G. Nowak

Department of Cytobiology, Jagiellonian University,

Collegium Medicum, Kraków, Poland and by an agonist of glycine B $_{\mathrm{B}}$ sites of the NMDA receptor complex, D-serine $[100 \mathrm{nmol} /$ mouse intracerebroventricularly (i.c.v.)]. The present study showed a positive interaction between $\gamma$-aminobutyric acid (GABA) and glutamate neurotransmission in the anxiolytic-like activity in the elevated plus-maze test in mice and this activity seems to particularly involve the NMDA receptors.

Keywords Chlordiazepoxide - NMDA receptor ligands . Anxiety $\cdot$ Elevated plus-maze $\cdot$ Mice

\section{Introduction}

$\gamma$-Aminobutyric acid (GABA) is the principal inhibitory neurotransmitter in the mammalian central nervous system (Sieghart 1995; Sieghart et al. 1999). Dysfunction of the central GABA system has long been associated with anxiety spectrum disorders (Nutt and Malizia 2001; Lydiard 2003; Nemeroff 2003). It is known that in both, humans and animals, positive modulators of $\mathrm{GABA}_{\mathrm{A}}$ ionotropic receptors produce anxiolytic-like activity, while the negative modulators evoke anxiety (Kalueff and Nutt 1996; Nutt and Malizia 2001). Thus, for many years, the leading treatment of anxiety disorders was benzodiazepines that enhance GABAergic inhibitory neurotransmission through allosteric modulation of $\mathrm{GABA}_{\mathrm{A}}$ receptors. They are still preferred due to their efficacy, rapid onset of action, and safety (Stahl 2002), but their adverse effects: sedation, cognitive impairments, undesirable interactions with other drugs, drug dependence and abuse mostly limited their use (Uhlenhuth et al. 1999; Stahl 2002). Moreover, these treatments are effective only in about $70 \%$ of patients and full remission is observed only in $40 \%$ of patients; thus, the novel therapeutic strategies are extensively sought. 
Glutamate, which is the chief excitatory neurotransmitter in the mammalian central nervous system, is widely distributed throughout the brain and mediates its effects via stimulation of ionotropic and metabotropic receptors (Kew and Kemp 2005). The ionotropic glutamate receptor family is ligand-gated channels divided into three groups named after their selective agonists [ $N$-methyl-D-aspartate (NMDA), $\alpha$-amino-3-hydroxyl-5-methyl-4-isoxazole-propionate (AMPA), and kainate] and their density is high in cortical and limbic regions being implicated in the mediation of fear and anxiety (Krystal et al. 1999). The preclinical data indicate that a number of different classes of NMDA receptor antagonists, acting at specific sites located on the NMDA receptor complex, produced anxiolytic-like activity in tests of anxiety in rodents (Dunn et al. 1989; Sharma and Kulkarni 1993; Płaźnik et al. 1994; Karcz-Kubicha et al. 1997; Kotlińska and Liljequist 1998; Przegaliński et al. 2000; Poleszak et al. 2004). In humans, memantine and D-cycloserine are effective in obsessive-compulsive disorder (Feusner et al. 2009; Abramowitz et al. 2009; Aboujaoude et al. 2009), and moreover, D-cycloserine was effective in post-traumatic stress disorder (Amiel and Mathew 2007). Despite these findings, the numerous adverse effects produced by competitive and non-competitive NMDA antagonist limited their potential clinical use (Tricklebank et al. 1989; Willetts et al. 1990). Profound side effects, typical for competitive and non-competitive NMDA receptor antagonist, do not occur after administration glycine B $_{\mathrm{B}}$ site modulators (Parsons et al. 1998). This modulatory site of the NMDA receptor complex is a co-agonist site with affinity for glycine and D-serine (Wood et al. 1989, 1996). Antagonists and partial agonist of glycine $_{\mathrm{B}}$ sites inhibit the function of the NMDA receptor complex and produce effects which are similar to those produced by competitive and non-competitive NMDA receptor antagonist. It was shown that glycine potentiated the action of glutamate at NMDA receptors (Johnson and Ascher 1987), and antagonists and partial agonist of the glycine ${ }_{B}$ sites inhibited the function of the NMDA receptor complex and produced anxiolytic-like action in several experimental models of anxiety (Karcz-Kubicha et al. 1997; Przegaliński et al. 1998; Kotlińska and Liljequist 1998).

In this study, we investigated the interaction between glycine $_{\mathrm{B}}$ sites ligands and benzodiazepine/GABA $\mathrm{A}_{\mathrm{A}}$ receptor ligand, chlordiazepoxide (CDP) in the elevated plusmaze test in mice.

\section{Materials and methods}

\section{Animals}

The experiments were carried out on adult male Albino Swiss mice (25-30 g) purchased from the licensed breeder
(Kołacz, Warsaw, Poland). The animals were kept in cages (up to 10 per cage) on a natural day-night cycle with free access to food and water and they were used after at least 7 days of acclimatization to laboratory conditions. Each experimental group consisted of 8-12 animals. The experimental protocol was approved by the Local Ethics Committee at the Medical University of Lublin (license no. 31/2007), and all the procedures were in strict compliance with the European Communities Council Directive of 24 November 1986 (86/609/EEC).

\section{Drug administration}

Chlordiazepoxide (CDP, Polfa-Poznań, Poland) was administered intraperitoneally (i.p.) $60 \mathrm{~min}$ before the test. L-701,324 (7-chloro-4-hydroxy-3-(3- phenoxy)phenylquinolin-2[1H]-one, Sigma) was suspended in a $1 \%$ aqueous solution of Tween 80 (POCH, Gliwice, Poland) and administered intraperitoneally (i.p.) $60 \mathrm{~min}$ before the test. NMDA (Sigma), CGP 37849 (DL-(E)-2-amino-4-methyl-5phosphono-3-pentenoic acid, Tocris), D-cycloserine (D-4amino-3-isoxazolidone, Sigma) were dissolved in $0.9 \%$ $\mathrm{NaCl}$ and administered i.p. and also administered $60 \mathrm{~min}$ before the test. D-Serine (Sigma) was also dissolved in $0.9 \% \mathrm{NaCl}$ and administered intracerebroventricularly (i.c.v.) $15 \mathrm{~min}$ before the test. I.c.v. administration was performed according to a modified method described by Lipman and Spencer (1980). Control animals received an i.p. or i.c.v. injection of a respective vehicle. The volume of vehicles or drug solutions for i.p. and i.c.v. administrations was $10 \mathrm{ml} / \mathrm{kg}$ and $5 \mu \mathrm{l}$ per mouse, respectively.

\section{Elevated plus-maze test}

The experiments were carried out on mice according to the method of Lister (1987). The plus-maze apparatus was made of black polyvinyl chloride and consisted of two open $(30 \times 5 \mathrm{~cm})$ and two enclosed $(30 \times 5 \times 15 \mathrm{~cm})$ arms. The arms extended from a central platform of $5 \times 5 \mathrm{~cm}$. The apparatus was mounted on a stable base raising it $38 \mathrm{~cm}$ above the floor and was illuminated by red light. The test consisted of placing a mouse in the center of the apparatus (facing an enclosed arm) and allowing it to freely explore the maze. The number of entries into the open arms and the time spent in these arms were scored for a 5-min test period. An entry was defined as placing all four paws within the boundaries of the arm. The following measures were obtained from the test: the total number of arm entries, the percentage of entries into the open arms, the time spent in the open arms expressed as a percentage of the time spent in both the open and closed arms. Anxiolytic activity was indicated by increases in time spent in open arms or in a greater number of open arm entries. Total 
number of entries into either type of an arm was used as a measure of the overall motor activity.

\section{Statistical analysis}

The obtained data were evaluated by two-way analysis of variance (ANOVA) followed by Bonferroni's post hoc test. All results are presented as a mean \pm standard error of the mean (SEM). A $p \leq 0.05$ was considered statistically significant.

\section{Results}

Anxiolytic-like effect of joint administration of CDP and CGP 37849 in the elevated plus-maze test

Chlordiazepoxide administered at a dose of $0.5 \mathrm{mg} / \mathrm{kg}$ or CGP 37849 administered at a dose of $0.312 \mathrm{mg} / \mathrm{kg}$, both given alone, did not change the percentage of the time spent and also entries into the open arms with the exception
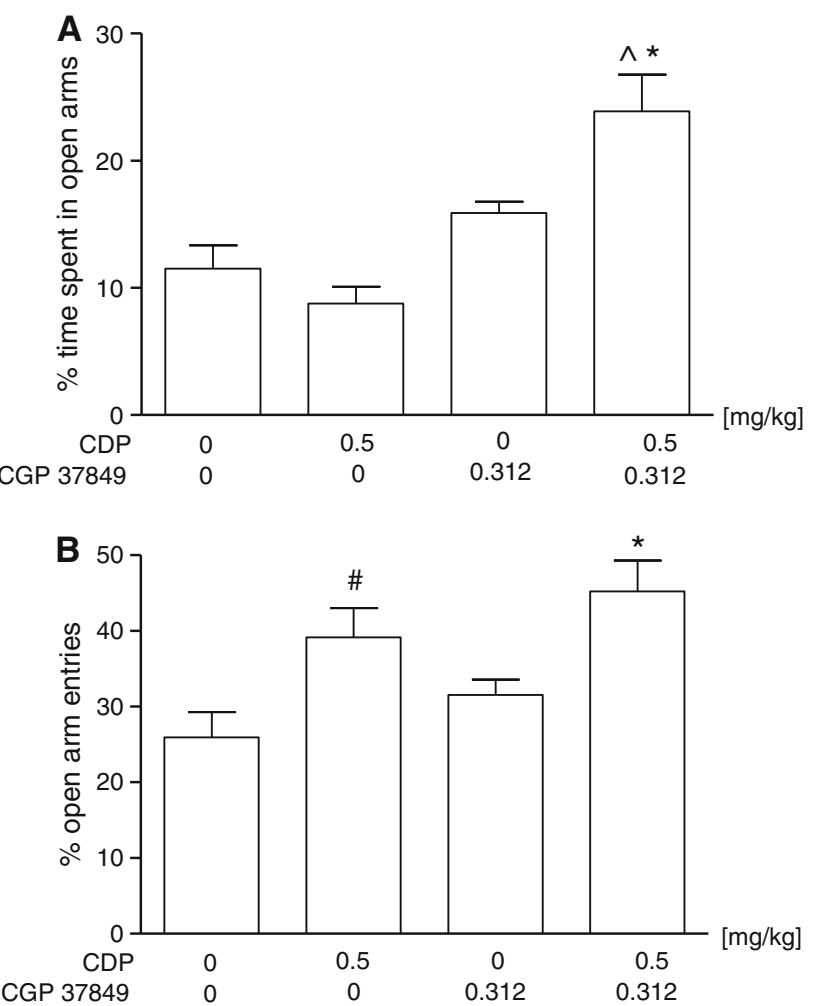

Fig. 1 Effect of joint administration of CGP 37849 and chlordiazepoxide (CDP) in the elevated plus-maze procedure in mice [the percentage of the time spent in the open arms (a), and the percentage of the open arms entries (b)]. CGP 37849 and CDP was administered i.p. $60 \mathrm{~min}$ before the test. The values represent the mean \pm SEM ( $n=8$ mice per group) $* p<0.05$ versus CGP $37849,{ }^{\wedge} p<0.001$ versus CDP, ${ }^{\#} p<0.05$ versus control (vehicle-treated group) (Bonferroni's test) of CDP, which significantly increased this latter measure (Fig. 1). The joint administration of CDP and CGP 37849 significantly increased the percentage of the time spent in the open arms (Fig. 1a) and enhanced the number of entries into open arms (Fig. 1b). A two-way ANOVA demonstrated lack of effect of $\operatorname{CDP}[F(1,28)=1.91$, $p=0.1777]$, significant effect of CGP $37849[F(1,28)=$ 26.38, $p<0.0001]$ and significant interaction $[F(1,28)=$ $8.02, p=0.0085]$ in the time spent in open arms, while a significant effect of CDP $[F(1,28)=15.301, p=0.0005]$, no effect of CGP $37849[F(1,28)=2.93, p=0.09882]$ and no interaction $[F(1,28)=0.0, p=0.9492]$ in the open arm entries.

Anxiolytic-like effect of joint administration of CDP and L-701,324 in the elevated plus-maze test

Chlordiazepoxide administered at a dose of $0.5 \mathrm{mg} / \mathrm{kg}$ did not alter the percentage of time spent and increased entries into the open arms (Fig. 2). L-701,324 given alone at a
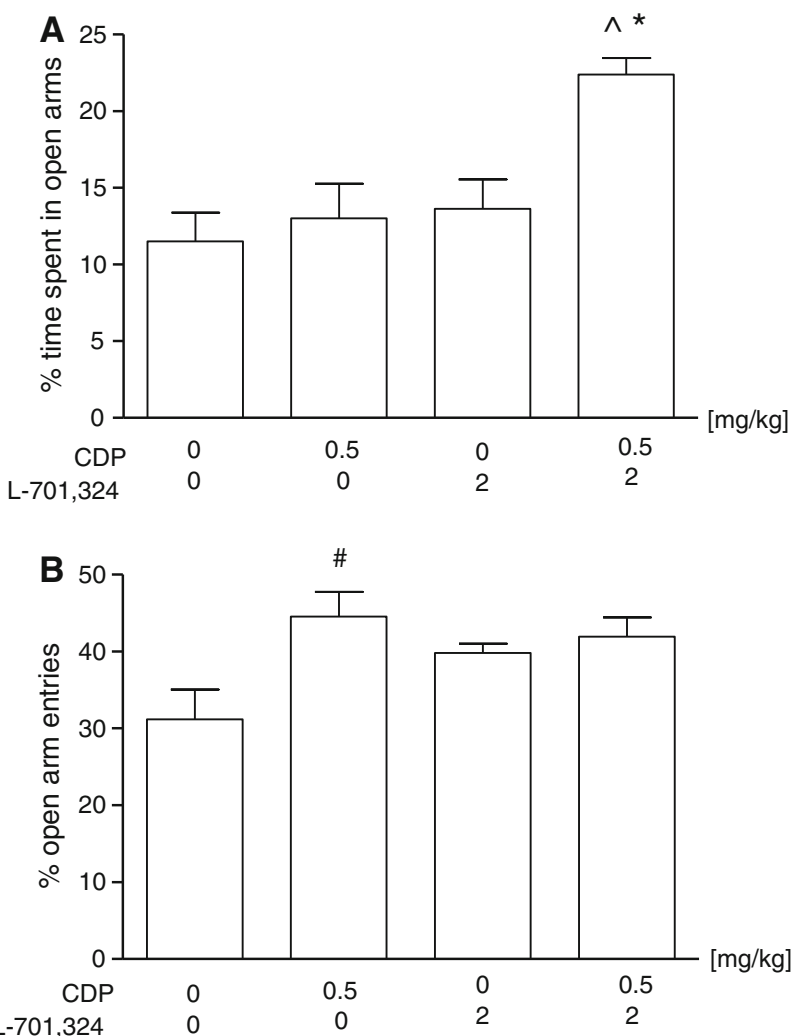

Fig. 2 Effect of joint administration of L-701,324 and chlordiazepoxide (CDP) in the elevated plus-maze procedure in mice [the percentage of the time spent in the open arms (a), and the percentage of the open arms entries (b)]. L-701,324 and CDP was administered i.p. $60 \mathrm{~min}$ before the test. The values represent the mean \pm SEM ( $n=8$ mice per group) $* p<0.01$ versus $\mathrm{L}-701,324,{ }^{\wedge} p<0.01$ versus $\mathrm{CDP},{ }^{\#} p<0.01$ versus control (vehicle-treated group) (Bonferroni's test) 
dose of $2 \mathrm{mg} / \mathrm{kg}$ exhibited no effect in this test (Fig. 2a, b). The joint administration of CDP and L-701,324 (both in ineffective per se doses) significantly increased the percentage of time spent in the open arms (Fig. 2a), but not in the number of entries into open arms (Fig. 2b). A two-way ANOVA demonstrated a significant effect of CDP $[F(1$, 28) $=7.66, p=0.0099]$, a significant effect of L-701,324 $[F(1,28)=9.65, p<0.0043]$ and not quite significant interaction $[F(1,28)=3.83, p=0.0603]$ in the time spent in open arms, while a significant effect of $\operatorname{CDP}[F(1,28)=$ $7.25, p=0.0118]$, no effect of L-701,324 $[F(1,28)=$ $1.09, p=0.3056]$ and not quite significant interaction $[F(1,28)=3.77, p=0.0622]$ in the open arm entries.

Anxiolytic-like effect of joint administration of CDP and D-cycloserine in the elevated plus-maze test

Chlordiazepoxide administered at a dose of $0.5 \mathrm{mg} / \mathrm{kg}$ did not change either the percentage of the time spent (Fig. 3a) or the number of entries into open arms (Fig. 3b).
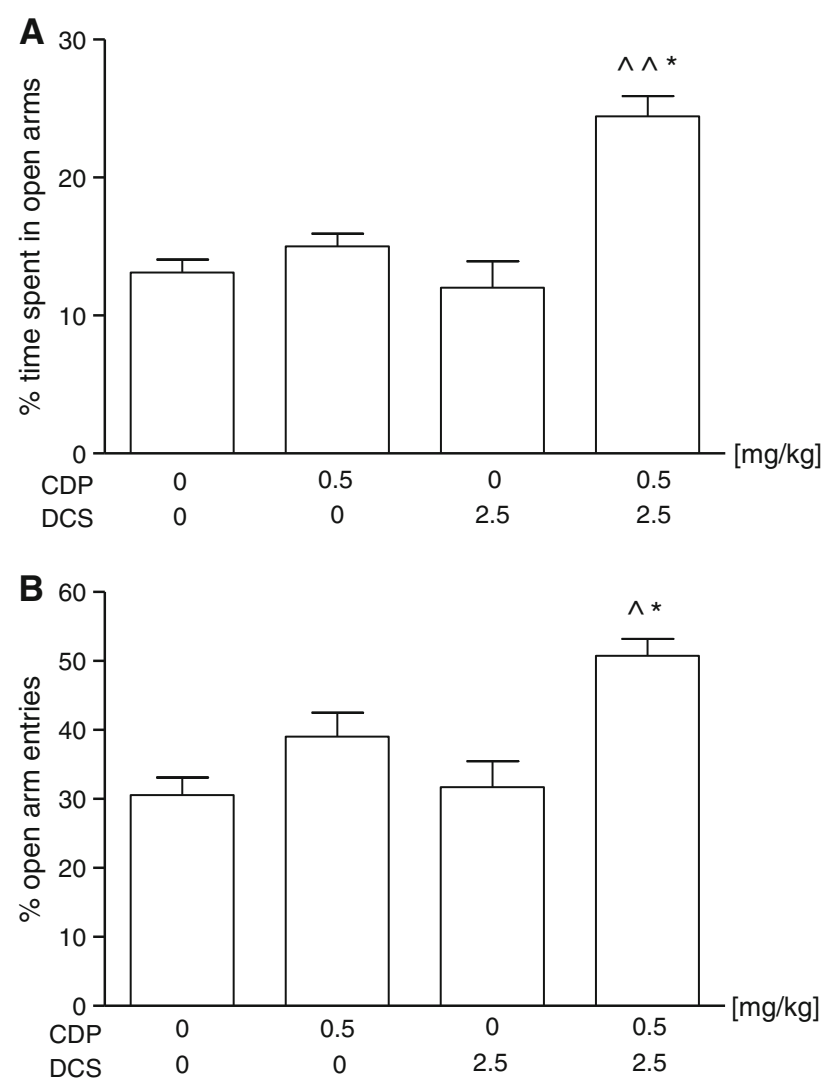

Fig. 3 Effect of joint administration of D-cycloserine (DCS) and chlordiazepoxide (CDP) in the elevated plus-maze procedure in mice [the percentage of the time spent in the open arms (a), and the percentage of the open arms entries (b)]. L-701,324 and CDP was administered i.p. $60 \mathrm{~min}$ before the test. The values represent the mean \pm SEM $(n=9-10$ mice per group) $* p<0.001$ versus DCS, $\hat{p}<0.05,{ }^{\wedge} p<0.001$ versus CDP (Bonferroni's test)
D-Cycloserine administered singly at a dose of $2.5 \mathrm{mg} / \mathrm{kg}$ remained also without any effect on both of these measures (Fig. 3a, b). CDP administered at an ineffective per se dose of $0.5 \mathrm{mg} / \mathrm{kg}$ and D-cycloserine administered at such a dose of $2.5 \mathrm{mg} / \mathrm{kg}$ significantly increased the percentage of the time spent in the open arms (Fig. 3a) and enhanced the number of entries into open arms (Fig. 3b). A two-way ANOVA demonstrated a significant effect of CDP $[F(1,34)=24.83, p<0.0001]$, a significant effect of DCS $[F(1,34)=8.73, p=0.0057]$ and a significant interaction $[F(1,34)=13.35, p=0.0009]$ in the time spent in the open arms, while a significant effect of CDP $[F(1,34)=19.50, p<0.0001]$, a significant effect of DCS $[F(1,34)=4.31, \quad p=0.0451]$ and no interaction $[F(1,34)=2.93, p=0.0956]$ in the open arm entries.

Effect of NMDA on the anxiolytic-like activity of CDP in the elevated plus-maze test

Chlordiazepoxide given at a dose of $2 \mathrm{mg} / \mathrm{kg}$ produced anxiolytic-like effect significantly increasing the percentage of the time spent in the open arms and increasing the percentage of the entries into the open arms (Fig. 4). The increase in percentage of the time spent in the open arms induced by CDP $(2 \mathrm{mg} / \mathrm{kg})$ was significantly reversed by NMDA $(75 \mathrm{mg} / \mathrm{kg})$ (Fig. 4a). The increase in the number of the open arm entries induced by CDP $(2 \mathrm{mg} / \mathrm{kg})$ was significantly decreased by NMDA (Fig. 4b). NMDA given alone had no effect on either the time spent or the entries into the open arms (Fig. 4). A two-way ANOVA demonstrated a significant effect of CDP $[F(1,36)=45.98$, $p<0.0001]$, a significant effect of NMDA $[F(1,36)=$ 21.37, $p<0.0001]$ and a significant interaction $[F(1$, $36)=21.19, p<0.0001]$ in the time spent in open arms, and a similarly significant effect of CDP $[F(1,36=15.87$, $p=0.0003]$, a significant effect of NMDA $[F(1,36)=$ $8.11, p=0.0072]$ and a significant interaction $[F(1,36)=$ $11.91, p=0.0014]$ in the open arm entries.

Effect of D-serine on the anxiolytic-like activity of CDP in the elevated plus-maze test

Chlordiazepoxide given at a dose of $2 \mathrm{mg} / \mathrm{kg}$ produced an anxiolytic-like effect significantly increasing the percentage of the time spent in the open arms and increasing the percentage of the entries into the open arms (Fig. 5). The increase in the percentage of the time spent in the open arms induced by CDP $(2 \mathrm{mg} / \mathrm{kg})$ was significantly reversed by D-serine (100 nmol/mouse) (Fig. 5a). The increase in the number of the open arm entries induced by CDP $(2 \mathrm{mg} / \mathrm{kg})$ was significantly changed by D-serine (Fig. 5b). D-Serine given alone had no effect on either the time spent or the entries into the open arms (Fig. 5). A two-way ANOVA 

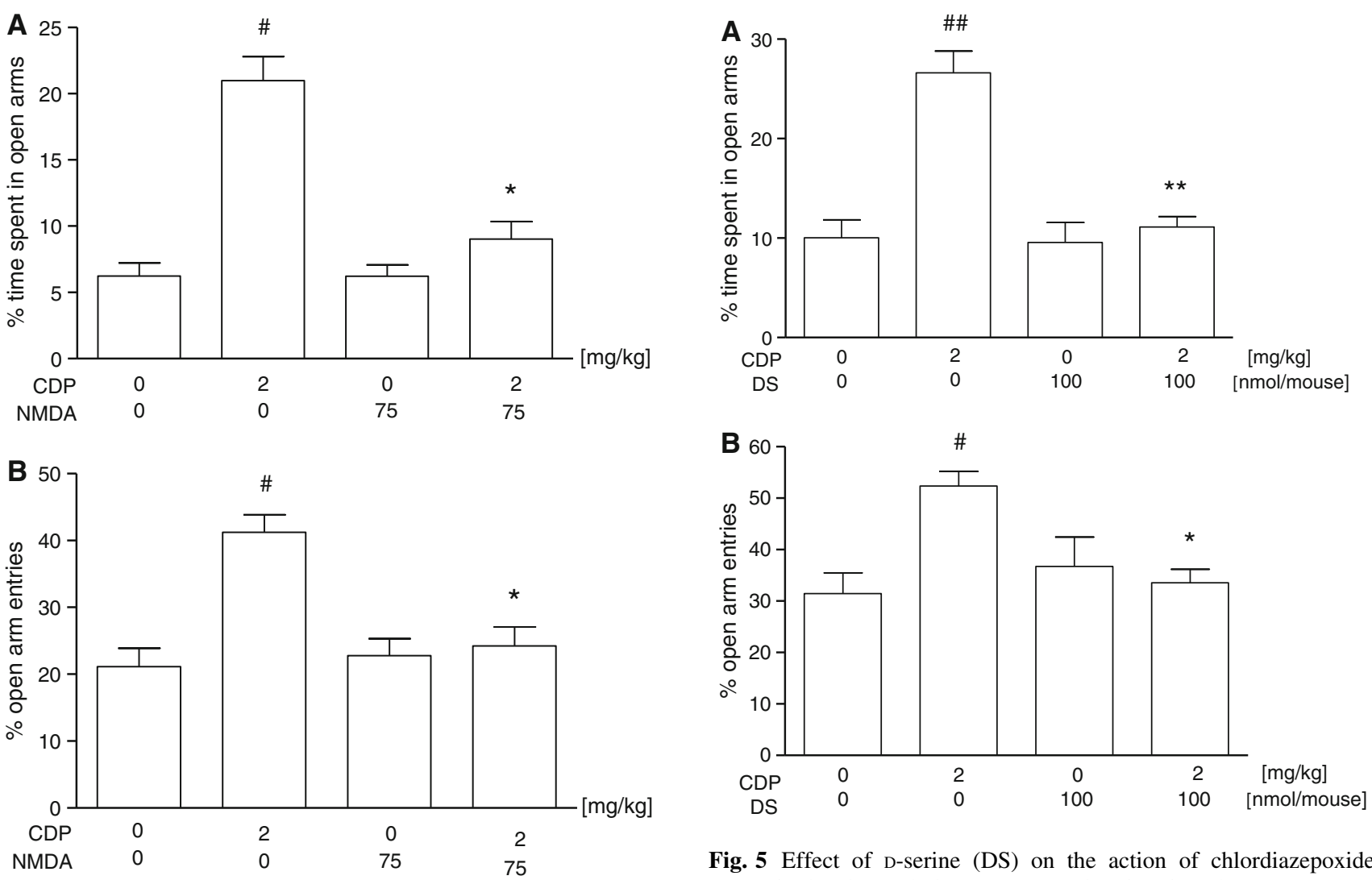

Fig. 5 Effect of D-serine (DS) on the action of chlordiazepoxide (CDP) in the elevated plus-maze procedure in mice [the percentage of the time spent in the open arms (a), and the percentage of the open arms entries (b)]. CDP was administered i.p. $60 \mathrm{~min}$ before the test, DS was administered i.c.v. $45 \mathrm{~min}$ after CDP injection. The values represent the mean $\pm \operatorname{SEM}(n=9-10$ mice per group) $* p<0.01$, ${ }^{* *} p<0.001$ versus CDP, ${ }^{\#} p<0.01,{ }^{\# \#} p<0.001$, versus control (vehicle-treated group) (Bonferroni's test)

\section{Discussion}

demonstrated a significant effect of $\operatorname{CDP}[F(1,33)=23.80$, $p<0.0001]$, a significant effect of D-serine $[F(1,33)=$ $18.49, p=0.0001]$ and a significant interaction $[F(1,33)=$ $16.33, p<0.0003$ ] in the time spent in the open arms, while a significant effect of $\operatorname{CDP}[F(1,33)=4.97, p=0.0321]$, no effect of D-serine $[F(1,33)=2.93, p=0.0957]$ and a significant interaction $[F(1,33)=9.11, p=0.0046]$ in the open arm entries.

Effect of CDP and NMDA ligands on the total arm entries

Chlordiazepoxide and all tested NMDA receptor ligands, administered singly or in combination, did not alter the number of the total arm entries (Table 1). A two-way ANOVA demonstrated the lack of the significant interaction between treatments in all analyzed experiments A: $F(1,28)=0.74, p=0.3964, \mathrm{~B}: F(1,28)=0.53, p=$ $0.4723], \mathrm{C}: F(1,36)=3.25, p=0.0797, \mathrm{D}: F(1,36)=$ $2.59, p=0.1164$, E: $F(1,36)=1.02, p=0.3185$.

A number of behavioral data have suggested the involvement of the glutamate-mediated neurotransmission in an anxiolytic-like behavior. The anxiolytic-like activity was demonstrated for different modulatory sites of NMDA receptor complex: for a non-competitive NMDA antagonist, dizocilpine (MK-801) (Dunn et al. 1989; Sharma and Kulkarni 1993; Karcz-Kubicha et al. 1997), a competitive NMDA antagonist, 2-amino-7-phosphoheptanoic acid (AP7) (Płaźnik et al. 1994), CGP 37849 (Przegaliński et al. 2000), and partial agonists of glycine ${ }_{\mathrm{B}}$ sites, D-cycloserine (Karcz-Kubicha et al. 1997) and 1-aminocyclo-propanecarboxylic acid (ACPC) (Trullas et al. 1989; Trullas et al. 1991), and antagonist of glycine ${ }_{B}$ sites: L-701,324 (KarczKubicha et al. 1997; Przegaliński et al. 1998; Kotlińska and Liljequist 1998). The anxiolytic-like profile of different NMDA antagonists was similar to that of benzodiazepines (Płaźnik et al. 1994) and the excitatory amino acid agonist, NMDA, produced anxiogenic-like effects in the elevated plus-maze test (Dunn et al. 1989). Moreover, genetic 
Table 1 The number of the total arm entries for all experimental groups

\begin{tabular}{ll}
\hline Treatment and dose & Number of total entries \\
\hline$A$ & \\
Vehicle & $12.63 \pm 0.46$ \\
CDP $0.5 \mathrm{mg} / \mathrm{kg}$ & $12.00 \pm 1.00$ \\
CGP $378490.312 \mathrm{mg} / \mathrm{kg}$ & $13.25 \pm 1.21$ \\
CDP $0.5 \mathrm{mg} / \mathrm{kg}$ and CGP $378490.312 \mathrm{mg} / \mathrm{kg}$ & $14.75 \pm 1.85$ \\
$B$ & \\
Vehicle & $14.38 \pm 1.75$ \\
CDP $0.5 \mathrm{mg} / \mathrm{kg}$ & $15.75 \pm 1.46$ \\
L-701,324 $2 \mathrm{mg} / \mathrm{kg}$ & $13.50 \pm 1.04$ \\
CDP $0.5 \mathrm{mg} / \mathrm{kg}$ and L-701,324 mg/kg & $16.75 \pm 0.59$ \\
$C$ & \\
Vehicle & $14.50 \pm 0.74$ \\
CDP $0.5 \mathrm{mg} / \mathrm{kg}$ & $11.44 \pm 0.67$ \\
D-cycloserine $2.5 \mathrm{mg} / \mathrm{kg}$ & $12.80 \pm 0.70$ \\
CDP $0.5 \mathrm{mg} / \mathrm{kg}$ and D-cycloserine $2.5 \mathrm{mg} / \mathrm{kg}$ & $12.00 \pm 0.92$ \\
$D$ & \\
Vehicle & $11.80 \pm 1.07$ \\
CDP $2 \mathrm{mg} / \mathrm{kg}$ & $15.30 \pm 1.90$ \\
NMDA $75 \mathrm{mg} / \mathrm{kg}$ & $13.20 \pm 0.53$ \\
CDP $2 \mathrm{mg} / \mathrm{kg}$ and NMDA $75 \mathrm{mg} / \mathrm{kg}$ & $12.80 \pm 0.92$ \\
$E$ & \\
Vehicle & $15.10 \pm 1.65$ \\
CDP $2 \mathrm{mg} / \mathrm{kg}$ & $19.30 \pm 0.71$ \\
D-serine $100 \mathrm{nmol} / \mathrm{mouse}$ & $12.40 \pm 1.33$ \\
CDP $2 \mathrm{mg} / \mathrm{kg}$ and D-serine $100 \mathrm{nmol} / \mathrm{mouse}$ & $17.40 \pm 1.32$ \\
\hline & \\
\hline & \\
\hline
\end{tabular}

Data represent the mean $\pm \mathrm{SEM} ; n=9-12$. Chlordiazepoxide (CDP), CGP 37849, L-701,324, D-cycloserine and $N$-methyl-Daspartate (NMDA) were administered i.p. $60 \mathrm{~min}$ before the test. D-serine was administered i.c.v. 15 min before the test

studies indicated an anxiolytic-like activity of NR2A subunit of NMDA receptor knockout mice (Boyce-Rustay and Holmes 2006). Validation of the elevated plus-maze procedure has shown that it is sensitive to drugs that produce anxiolytic or anxiogenic effects in human (Pellow et al. 1985), including drugs that have non-benzodiazepine sites of action (Pellow 1986). Moreover, in the clinical study showed useful of memantine (non-competitive NMDA receptor antagonist) augmentation in treatment-resistant obsessive-compulsive disorder (Feusner et al. 2009; Aboujaoude et al. 2009), D-cycloserine (partial agonists of glycine $_{\mathrm{B}}$ sites) (Hood et al. 1989; Emmett et al. 1991) as a potential therapeutic agent for post-traumatic stress disorder and specific phobia (Heresco-Levy et al. 2002; Ressler et al. 2004), and riluzole in the treatment of symptoms obsessive-compulsive disorder (Coric et al. 2005) and general anxiety disorder (Mathew et al. 2005).
In the present study, we have demonstrated the influence of NMDA receptor ligands on anxiolytic-like activity of CDP in the elevated plus-maze in mice. We have shown that a competitive NMDA antagonist (CGP 37849), partial agonist of the glycine ${ }_{B}$ site (D-cycloserine) and glycine ${ }_{B}$ antagonist $($ L-701,324) enhanced the anxiolytic-like activity of CDP in the elevated plus-maze. The previous study has shown that CGP 37849 evoked potentially anxiolyticlike effects in the Vogel conflict drinking test, an open field test (Płaźnik et al. 1994) and in the elevated plus-maze test in rats and its anxiolytic-like activity was abolished by flumazenil (Przegaliński et al. 2000). In our study, $0.312 \mathrm{mg} / \mathrm{kg}$ CGP 37849 produced synergistic effects with CDP $(0.5 \mathrm{mg} / \mathrm{kg})$ in the elevated plus-maze test in mice. Unfortunately, the side effects produced by competitive and uncompetitive NMDA antagonist (motor impairment, hyperactivity, stereotypy and psychotomimetic actions (Willetts et al. 1990) limited their potential use for the treatment in humans. After the discovery that the NMDA receptor activity is regulated by co-agonist (glycine or D-serine), numerous studies concentrated on this pathway. It is known that a co-agonist site exerts major regulatory roles in the activity of NMDA receptor complex. The binding of the co-agonist (glycine or D-serine) is an obligatory requirement for NMDA receptor/channel activity (Johnson and Ascher 1987; Kleckner and Dingledine 1988). More recently, studies have shown that selective blockers of the co-agonist site abolish NMDA receptor activity (Kessler et al. 1989; Kleckner and Dingledine 1989) and produced pharmacological effects similar to those exerted after the administration of a competitive and non-competitive NMDA antagonist. D-Cycloserine has a profile of a partial agonist acting at the glycine binding site (Hood et al. 1989; Watson et al. 1990). In the preclinical data D-cycloserine exhibits anxiolytic-like effects in the Vogel conflict test (Kłodzińska and Chojnacka-Wójcik 2000), in the elevated plus-maze (time in open arms) (Karcz-Kubicha et al. 1997; Ho et al. 2005; Poleszak et al. 2008), and in a fear-potentiated startle response test (Anthony and Nevins 1993) (Campeau et al. 1992; Fendt et al. 1996). The glycine B $_{\mathrm{B}}$ receptor antagonist (L-701,324) has produced anxiolytic-like effects in the elevated plusmaze test and the four-plate test (Karcz-Kubicha et al. 1997; Przegaliński et al. 1998; Kotlińska and Liljequist 1998).

In our study, the combined treatment with CDP and L-701,324 (a glycine ${ }_{\mathrm{B}}$ site antagonist) or D-cycloserine (a glycine site partial agonist), all at low, ineffective doses, increased the time spent in the open arms of the elevated plus-maze, with no effects on the number of total entries (Table 1). Because the obtained data indicate a lack of effect on the locomotor activity, we can assume that this combination produced an anxiolytic-like activity. The 
anxiolytic-like activity of CDP was reduced by NMDA or by $\mathrm{D}$-serine, what suggests the involvement of NMDA receptor complex in the anxiolytic activity of CDP in the elevated plus-maze in mice. The interaction between NMDA and GABAergic neurotransmission in anxiety assessments in animals was shown in other experiments. The anxiolytic-like activity of MK-801 was enhanced by diazepam, antagonized by the benzodiazepine receptor antagonist (Ro-15-1788) and reversed by the anxiogenic agent, $\beta$-carboline FG-7142 (Sharma and Kulkarni 1993).

To summarize, the present study indicates the involvement of the NMDA receptor complex in the anxiolytic-like activity of CDP in the EMP in mice. Our results also suggest that full anxiolysis might be possible with a reduced dose of benzodiazepines when co-administered with NMDA receptor antagonists and this might substantially reduce side effects and the risk of the benzodiazepine dependence. Clinical trials are necessary to determine if such a combination is of a potentially therapeutic value in humans with anxiety disorders.

Acknowledgments This study was supported by Funds for Statutory Activity of Medical University of Lublin, Maria Curie-Skłodowska University, Lublin, Institute of Pharmacology, Polish Academy of Sciences, and Jagiellonian University Collegium Medicum, Kraków, Poland.

Conflict of interest The authors declare they have no conflict of interest.

Open Access This article is distributed under the terms of the Creative Commons Attribution Noncommercial License which permits any noncommercial use, distribution, and reproduction in any medium, provided the original author(s) and source are credited.

\section{References}

Aboujaoude E, Barry JJ, Gamel N (2009) Memantine augmentation in treatment-resistant obsessive-compulsive disorder: an openlabel trial. J Clin Psychopharmacol 29:51-55

Abramowitz JS, Taylor S, McKay D (2009) Obsessive-compulsive disorder. Lancet 374:491-499

Amiel JM, Mathew SJ (2007) Glutamate and anxiety disorders. Curr Psychiatry Rep 9:278-283

Anthony EW, Nevins ME (1993) Anxiolytic-like effects of $N$-methylD-aspartate-associated glycine receptor ligands in the rat potentiated startle test. Eur J Pharmacol 250:317-324

Boyce-Rustay JM, Holmes A (2006) Genetic inactivation of the NMDA receptor NR2A subunit has anxiolytic- and antidepressant-like effects in mice. Neuropsychopharmacology 31:24052414

Campeau S, Miserendino MJ, Davis M (1992) Intra-amygdala infusion of the $N$-methyl-D-aspartate receptor antagonist AP5 blocks acquisition but not expression of fear-potentiated startle to an auditory conditioned stimulus. Behav Neurosci 106:569-574

Coric V, Taskiran S, Pittenger C, Wasylink S, Mathalon DH, Valentine G, Saksa J, Wu YT, Gueorguieva R, Sanacora G,
Malison RT, Krystal JH (2005) Riluzole augmentation in treatment-resistant obsessive-compulsive disorder: an open-label trial. Biol Psychiatry 58:424-428

Dunn RW, Corbett R, Fielding S (1989) Effects of 5-HT1A receptor agonists and NMDA receptor antagonists in the social interaction test and the elevated plus maze. Eur J Pharmacol 169:1-10

Emmett MR, Mick SJ, Cler JA, Rao TS, Iyengar S, Wood PL (1991) Actions of D-cycloserine at the $N$-methyl-D-aspartate-associated glycine receptor site in vivo. Neuropharmacology 30:1167-1171

Fendt M, Koch M, Schnitzler HU (1996) NMDA receptors in the pontine brainstem are necessary for fear potentiation of the startle response. Eur J Pharmacol 318:1-6

Feusner JD, Kerwin L, Saxena S, Bystritsky A (2009) Differential efficacy of memantine for obsessive-compulsive disorder vs. generalized anxiety disorder: an open-label trial. Psychopharmacol Bull 42:81-93

Heresco-Levy U, Kremer I, Javitt DC, Goichman R, Reshef A, Blanaru M, Cohen T (2002) Pilot-controlled trial of D-cycloserine for the treatment of post-traumatic stress disorder. Int $\mathrm{J}$ Neuropsychopharmacol 5:301-307

Ho YJ, Hsu LS, Wang CF, Hsu WY, Lai TJ, Hsu CC, Tsai YF (2005) Behavioral effects of D-cycloserine in rats: the role of anxiety level. Brain Res 1043:179-185

Hood WF, Compton RP, Monahan JB (1989) D-cycloserine: a ligand for the $N$-methyl-D-aspartate coupled glycine receptor has partial agonist characteristics. Neurosci Lett 98:91-95

Johnson JW, Ascher P (1987) Glycine potentiates the NMDA response in cultured mouse brain neurons. Nature 325:529-531

Kalueff A, Nutt DJ (1996) Role of GABA in memory and anxiety. Depress Anxiety 4:100-110

Karcz-Kubicha M, Jessa M, Nazar M, Plaźnik A, Hartmann S, Parsons CG, Danysz W (1997) Anxiolytic activity of glycine-B antagonists and partial agonists-no relation to intrinsic activity in the patch clamp. Neuropharmacology 36:1355-1367

Kessler M, Terramani T, Lynch G, Baudry M (1989) A glycine site associated with $\mathrm{N}$-methyl-D-aspartic acid receptors: characterization and identification of a new class of antagonists. J Neurochem 52:1319-1328

Kew JN, Kemp JA (2005) Ionotropic and metabotropic glutamate receptor structure and pharmacology. Psychopharmacology (Berl) 179:4-29

Kleckner NW, Dingledine R (1988) Requirement for glycine in activation of NMDA-receptors expressed in Xenopus oocytes. Science 241:835-837

Kleckner NW, Dingledine R (1989) Selectivity of quinoxalines and kynurenines as antagonists of the glycine site on $N$-methyl-Daspartate receptors. Mol Pharmacol 36:430-436

Kłodzińska A, Chojnacka-Wójcik E (2000) Anticonflict effect of the glycine $_{\mathrm{B}}$ receptor partial agonist, D-cycloserine, in rats. Pharmacological analysis. Psychopharmacology (Berl) 152:224-228

Kotlińska J, Liljequist S (1998) A characterization of anxiolytic-like actions induced by the novel NMDA/glycine site antagonist, L-701, 324. Psychopharmacology (Berl) 135:175-181

Krystal JH, D'Souza DC, Petrakis IL, Belger A, Berman RM, Charney DS, Abi-Saab W, Madonick S (1999) NMDA agonists and antagonists as probes of glutamatergic dysfunction and pharmacotherapies in neuropsychiatric disorders. Harv Rev Psychiatry 7:125-143

Lipman JJ, Spencer PS (1980) Rapid intracerebroventricular injection assisted by an automatic syringe. J Pharmacol Methods 4:327333

Lister RG (1987) The use of a plus-maze to measure anxiety in the mouse. Psychopharmacology (Berl) 92:180-185

Lydiard RB (2003) The role of GABA in anxiety disorders. J Clin Psychiatry 64(Suppl 3):21-27 
Mathew SJ, Amiel JM, Coplan JD, Fitterling HA, Sackeim HA, Gorman JM (2005) Open-label trial of riluzole in generalized anxiety disorder. Am J Psychiatry 162:2379-2381

Nemeroff CB (2003) The role of GABA in the pathophysiology and treatment of anxiety disorders. Psychopharmacol Bull 37:133146

Nutt DJ, Malizia AL (2001) New insights into the role of the $\mathrm{GABA}_{\mathrm{A}}$-benzodiazepine receptor in psychiatric disorder. $\mathrm{Br} \mathrm{J}$ Psychiatry 179:390-396

Parsons CG, Danysz W, Quack G (1998) Glutamate in CNS disorders as a target for drug development: an update. Drug News Perspect 11:523-569

Pellow S (1986) Anxiolytic and anxiogenic drug effects in a novel test of anxiety: are exploratory models of anxiety in rodents valid? Methods Find Exp Clin Pharmacol 8:557-565

Pellow S, Chopin P, File SE, Briley M (1985) Validation of open:closed arm entries in an elevated plus-maze as a measure of anxiety in the rat. J Neurosci Methods 14:149-167

Płaźnik A, Pałejko W, Nazar M, Jessa M (1994) Effects of antagonists at the NMDA receptor complex in two models of anxiety. Eur Neuropsychopharmacol 4:503-512

Poleszak E, Szewczyk B, Kędzierska E, Wlaź P, Pilc A, Nowak G (2004) Antidepressant- and anxiolytic-like activity of magnesium in mice. Pharmacol Biochem Behav 78:7-12

Poleszak E, Wlaź P, Wróbel A, Fidecka S, Nowak G (2008) NMDA/ glutamate mechanism of magnesium-induced anxiolytic-like behavior in mice. Pharmacol Rep 60:655-663

Przegaliński E, Tatarczyńska E, Chojnacka-Wójcik E (1998) Anxiolytic- and antidepressant-like effects of an antagonist at glycine ${ }_{\mathrm{B}}$ receptors. Pol J Pharmacol 50:349-354

Przegaliński E, Tatarczyńska E, Chojnacka-Wójcik E (2000) The influence of the benzodiazepine receptor antagonist flumazenil on the anxiolytic-like effects of CGP 37849 and ACPC in rats. Neuropharmacology 39:1858-1864

Ressler KJ, Rothbaum BO, Tannenbaum L, Anderson P, Graap K, Zimand E, Hodges L, Davis M (2004) Cognitive enhancers as adjuncts to psychotherapy: use of D-cycloserine in phobic individuals to facilitate extinction of fear. Arch Gen Psychiatry 61:1136-1144

Sharma AC, Kulkarni SK (1993) Evidence for benzodiazepine receptor interaction with MK 801 in anxiety related behaviour in rats. Indian J Exp Biol 31:191-193
Sieghart W (1995) Structure and pharmacology of gamma-aminobutyric acid $_{\mathrm{A}}$ receptor subtypes. Pharmacol Rev 47:181-234

Sieghart W, Fuchs K, Tretter V, Ebert V, Jechlinger M, Hoger H, Adamiker D (1999) Structure and subunit composition of $\mathrm{GABA}_{\mathrm{A}}$ receptors. Neurochem Int 34:379-385

Stahl SM (2002) Don't ask, don't tell, but benzodiazepines are still the leading treatments for anxiety disorder. J Clin Psychiatry 63:756-757

Tricklebank MD, Singh L, Oles RJ, Preston C, Iversen SD (1989) The behavioural effects of MK-801: a comparison with antagonists acting non-competitively and competitively at the NMDA receptor. Eur J Pharmacol 167:127-135

Trullas R, Jackson B, Skolnick P (1989) Anxiolytic properties of 1-aminocyclopropanecarboxylic acid, a ligand at strychnineinsensitive glycine receptors. Pharmacol Biochem Behav 34:313-316

Trullas R, Folio T, Young A, Miller R, Boje K, Skolnick P (1991) 1Aminocyclopropanecarboxylates exhibit antidepressant and anxiolytic actions in animal models. Eur J Pharmacol 203:379-385

Uhlenhuth EH, Balter MB, Ban TA, Yang K (1999) International study of expert judgment on therapeutic use of benzodiazepines and other psychotherapeutic medications: IV. Therapeutic dose dependence and abuse liability of benzodiazepines in the longterm treatment of anxiety disorders. J Clin Psychopharmacol 19:23S-29S

Watson GB, Bolanowski MA, Baganoff MP, Deppeler CL, Lanthorn TH (1990) D-cycloserine acts as a partial agonist at the glycine modulatory site of the NMDA receptor expressed in Xenopus oocytes. Brain Res 510:158-160

Willetts J, Balster RL, Leander JD (1990) The behavioral pharmacology of NMDA receptor antagonists. Trends Pharmacol Sci 11:423-428

Wood PL, Emmett MR, Rao TS, Mick S, Cler J, Iyengar S (1989) In vivo modulation of the $N$-methyl-D-aspartate receptor complex by D-serine: potentiation of ongoing neuronal activity as evidenced by increased cerebellar cyclic GMP. J Neurochem 53:979-981

Wood PL, Hawkinson JE, Goodnough DB (1996) Formation of Dserine from L-phosphoserine in brain synaptosomes. J Neurochem 67:1485-1490 